identified some years ago were studied in detail. An airborne radiometric survey was followed by a detailed sampling programme over the areas of pyrochlore mineralisation. More than 1000 chip samples were systematically collected from the $1400 \mathrm{~m}$ high steep mountain faces by mountaineers. The project was financed by a special grant from the Mineral Resources Administration.

\section{General}

GGU inspected the mineral exploration activities of concessionaires at Disko-Nûgssuaq, Ivigtut, Narsaq, Kangerdluarssuk and Nanortalik in West and South Greenland, and at Kangerdlugssuaq and Jameson Land in East Greenland, as well as followed the activities at the Sorte Engel mine at Mârmorilik. The mining activity at Ivigtut was stopped in December 1987. The pit is now filled with sea water and all cryolite from the stock piles has been shipped to Copenhagen. Assistance was also provided to the Mineral Resources Administration in negotiations with applicants for concessions and in the evaluation of concessionaires' reports.
Aeromagnetic measurements, essentially covering the eastern and western part of the Inland Ice south of $66^{\circ} \mathrm{N}$, were continued in co-operation with the Geological Survey of Canada and the National Aeronautical Establishment of Canada.

The 'Nordolie' programme funded by the Danish Ministry of Energy since 1984 was completed by the end of the year. The final project report, giving an evaluation of the hydrocarbon potential of central North Greenland, will be published by the Survey.

During the year the 1:500 000 Quaternary map sheet covering South Greenland was printed as well as three geological maps at 1:100 000 from West Greenland (Agpat 70 V. $2 \mathrm{~N}$; Mellemfjord 69 V.1 N; Isukasia 65 V.2 S). A special Quaternary map at a scale of 1:125000 along the coastal area of Jameson Land (East Greenland) was printed as well as a detailed (1:7500) map of the scheelite-bearing rocks at Store Malene near Nuuk. Four Reports, two Bulletins and a Map Sheet Description (Mârmorilik, Nûgâtsiaq, Pangnertôq) were published. As a result of GGU activities 36 contributions appeared in international scientific journals in 1987.

\title{
Introduction of new computing facilities at the Geological Survey of Greenland
}

\author{
Leif Thorning
}

From a cautious start in the use of computers in the early 1970s, the Geological Survey of Greenland has developed complex and varied uses of modern computer facilities for both scientific and administrative tasks. GGU's first computer installation, a noisy TTY connected to the Computing Centre of Copenhagen University by a 110 baud telephone modem, was a selfservice facility which was not easy to use. Over the years, first with use of a PDP-10 with just one Tektronix 4014 graphic terminal and later a succession of increasingly powerful PDP-11s with many terminals, GGU's in-house facilities just kept ahead of the ever increasing demand for computer services. At the same time a number of programs for special tasks were developed on external facilities, because they required larger computers or special facilities. In the 1980 s the demands on the computer facilities requiring many different types of programs, including word processing, had grown so large that GGU's in-house system could no longer handle them satisfactorily. A major reorganisation was re- quired, and consequently activities were divided between personal computers (PCs; mainly administrative) and a new central computer (mainly scientific). This development took place in late 1986 with the purchase of 17 new personal computers and a new central computer with accessory peripheral equipment. This has allowed an increasing integration of computer methods into GGU's activities. A brief summary is given below.

\section{Hardware}

The new central computer facility brought into use in January 1987 is a VAX-8200 system in a Digital network (ethernet with Decservers). Two tape stations and three disk drives are attached to the system. Most terminals are of the VT200 series, but there are also graphic terminals (see below). Several printers, among them two laser printers and a high quality plotter (CalComp 1044GT), provide all necessary types of output. The system includes an interface (PSI, X25) for communi- 


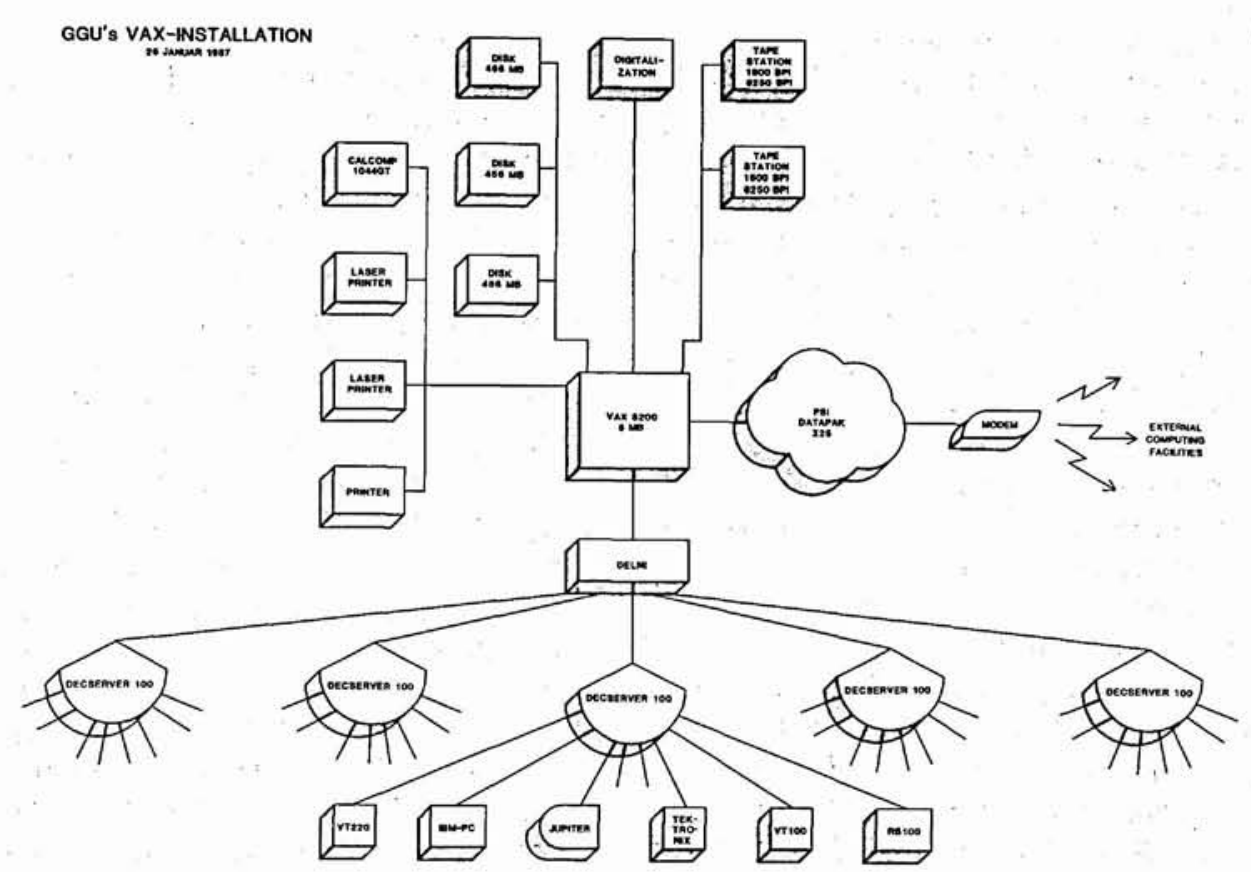

Fig. 1. Schematic diagram of GGU's VAX installation, at 26 January 1987.

cation with other computers. The main components of the system are shown with some specifications in fig. 1. All data and most programs were transferred from the old machine, a PDP-11/44; the change of system caused very little disruption of work. Two main objectives, viz. greater stability and larger capacity, were thus gained almost immediately.

There are several other local computer installations in GGU. These are used for various data-gathering activities in laboratories, e.g. in the chemical analysis laboratory (Hewlett-Packard and PDP-11), the photogeological laboratory (Hewlett-Packard), and the petrophysical laboratory (Hewlett-Packard), and they are all directly or indirectly connected to the central computer to facilitate transfer of data for further processing and interpretation. About 20 personal computers (IBM PC/XT and Rainbow 100+) are connected to the VAX computer and can be used on their own or as VT220 or VT100 compatible terminals. They are used for word processing, minor data bases and other local tasks.

Digitization is performed on a 'stand-alone' microcomputer system with a large Summagraphics table. The PC used for this (Comet 3400) provides a userfriendly interface with local editing and processing of data, and is connected to the VAX so that data can be transferred for further processing and plotting. Other graphical devices are Tektronix 4014 terminals with hard copy units, a Tektronix 4105 with colour printer, and a Jupiter 7+ high-resolution, colour screen soon to be extended with a colour printer.

A considerable amount of processing is still done on external computers, notably on two mainframes in Copenhagen belonging to UNI-C (Danish Computing Center for Research and Education) but also on smaller installations, e.g. IDIMS at the Technical University of Denmark used for image processing. Except for the latter, communication takes place through the public data net (DATAPAK, X25). Most of the geophysical computer work which has the longest history in computing at GGU is in this category. Examples are processing of large amounts of airborne geophysical data at UNI-C using GGU programs, or seismic processing done by contractors on specialized computers abroad.

\section{Software and applications}

GGU's software policy operates with three levels of programs, excluding the operating system itself. The highest level includes standard commercial programs from Digital Equipment Corporation (e.g. Fortran and Pascal compilers; Rdb, a relational data base management system; DATATRIEVE, a query and reporting program; FMS, a forms management program; CDD, a common data dictionary system; PSI, a communication program) or from other companies (e.g. GPGS, a subroutine and program library for plotting; BMDP, a sta- 
tistical package; LEX, a word processing program; SPIDER, a library of image processing routines; NAG, a library of numerical algorithms). The next level is composed of what are termed 'GGU programs', programs originally written by GGU employees or obtained from elsewhere and installed at GGU. These programs are maintained by GGU's computing group, because they are useful to large groups in GGU. Examples are programs for geographical transformations, plotting of maps and geochemical analyses, norm calculations, etc. The third level consists of 'user programs', maintained by the users themselves for their own use. This level includes several programs running on external computers and many sequential file data bases on a personal/ departmental basis.

Many and varied jobs, including programs for most types of geoscience interpretation work, are run on GGU's VAX computer by nearly 60 regular users. Three programmers assist the users in different ways and a computer scientist will be added to the staff in the spring of 1988. Both development and production type processing take place.

\section{Trends for the near future}

Recently, GGU's needs and obligations for central data bases were analyzed by an internal working group which recommended the construction of central GGU data bases for scientific data. The development of the central data bases will take place in steps, starting with scientific information related to geological samples (sample information, sample description, results of analyses) and later moving on to other types of data, e.g. map-related data with areal extent, glaciological data, etc.

Another main trend which GGU has already embarked upon is the increased integration of map plotting facilities.

An increased integration of the processing of mineralogical/chemical analyses and interpretation, based on results from samples, is foreseen.

Image processing has been used by GGU in various areas. Suitable software will be installed, thus gradually updating GGU's capability for data synthesis, based on information from GGU's data bases and from other sources. In some cases closer ties will be established to GGU's map production facilities. To some extent this has already happened for data types which are well suited for computer handling, e.g. geophysical and geochemical data.

In general, GGU's strategy calls for increasing integration and rationalization of computer application, including transfer of GGU programs from external computer facilities to GGU's VAX-8200. Hardware build-up will take advantage of the network facilities provided by DEC A/S.

\title{
Geological reconnaissance in the Precambrian basement of the Atâ area, central West Greenland
}

\author{
C. Knudsen, P. W. U. Appel, B. Hageskov and L. Skjernaa
}

Geological reconnaissance was carried out in July 1987 as part of regional geological investigations planned for 1986-1992. The field work was carried out from three field camps with logistic support from GGU cutter 'J. F. Johnstrup', a helicopter and a rubber dinghy. The mapping was made on aerial photographs.

\section{General geology}

The area has been mapped on a reconnaissance scale (map sheet 1:500 000) and is described by Escher \& Burri (1967). Kalsbeek et al. (in press) made an isotopegeochemical study of some of the rocks in the area. Steenfelt (1987) carried out a regional stream-sediment geochemical programme, and the mining companies
Kryolitselskabet Øresund A/S and Vestgron Mines Ltd. have prospected in the area.

Escher \& Burri (1967) divided the rocks in the area into the infracrustal Jakobshavn gneiss and Atâ granite, and the Anap nunâ supracrustals (fig. 1). They described a gradual transition from the mainly granodioritic and locally migmatitic Jakobshavn gneiss to the very little deformed Atâ granite. Escher \& Pulvertaft (1976) described the rocks as belonging to the Proterozoic Rinkian mobile belt (a continuation of the Foxe fold belt in Baffin Island) because dome and basin type structures described by Escher \& Burri (1967) resemble those of the Rinkian. Escher \& Pulvertaft describe the area as separated from the Proterozoic Nagssugtoqidian mobile belt to the south by the Pâkitsoq shear zone. 